\title{
O088: Bad design, bad practices, bad bugs - Elizabethkingia meningoseptica outbreak in ICU
}

\author{
S Salmon ${ }^{*}$, M Balm², C Teo ${ }^{1}$, R Mahdi', D Fisher ${ }^{1}$ \\ From 2nd International Conference on Prevention and Infection Control (ICPIC 2013) \\ Geneva, Switzerland. 25-28 June 2013
}

\section{Introduction}

Elizabethkingia meningoseptica is a nosocomial-adapted, Gram negative bacillus with intrinsic resistance to most antibiotics. An outbreak investigation was commenced when five patients developed E. meningoseptica bacteraemia within a three week period in the Cardiothoracic Intensive Care Unit (CTICU) and Surgical ICU (SICU).

\section{Methods}

Analysis of laboratory data, case reviews, workflows within CTICU and extensive environmental sampling of surfaces and taps within four ICU wards, four general wards, two dialysis units and eight operating theatres were performed.

\section{Results}

Upon review laboratory data revealed an unrecognized subtle increasing trend of $E$. meningoseptica clinical infections in all ICUs over the preceding 3 years. E. meningoseptica was cultured from aerators of $44 \%$ (35/79) taps. Taps in sinks frequently used for non-sanctioned practices were more likely to be contaminated (95\% CI 1.2-2.3, $\mathrm{p}<0.003)$. Elizabethkingia was not cultured from any other surfaces within patient rooms. Investigation of ICU nursing practice revealed introduction of non-sanctioned practices regarding disposal of patient respiratory secretions and cleaning of patient equipment in designated hand hygiene sinks within patient rooms. An urgent education programme was instituted to change these practices. Rooms underwent terminal cleaning. Faucets were systematically cleaned and aerators were changed. No further cases occurred in SICU or CT-ICU over the following three months. One month after aerator change, new aerators remained free of $E$. meningoseptica.

${ }^{1}$ Infection Control Team, National University Hospital Singapore, Singapore, Singapore

Full list of author information is available at the end of the article

\section{Conclusion}

Introduction of non-sanctioned practices due to suboptimal unit design may have unintended consequences for vulnerable patients. Nursing workflows must also be practical to ensure proper waste disposal and cleaning of medical equipment.

\section{Disclosure of interest}

None declared.

\section{Author details}

${ }^{1}$ Infection Control Team, National University Hospital Singapore, Singapore, Singapore. ${ }^{2}$ Microbiology, National University Hospital Singapore, Singapore, Singapore.

Published: 20 June 2013

\section{doi:10.1186/2047-2994-2-S1-088}

Cite this article as: Salmon et al:: O088: Bad design, bad practices, bad bugs - Elizabethkingia meningoseptica outbreak in ICU. Antimicrobial Resistance and Infection Control 2013 2(Suppl 1):088.

Submit your next manuscript to BioMed Central and take full advantage of:

- Convenient online submission

- Thorough peer review

- No space constraints or color figure charges

- Immediate publication on acceptance

- Inclusion in PubMed, CAS, Scopus and Google Scholar

- Research which is freely available for redistribution

\section{Biomed Central}

